\begin{tabular}{|c|c|c|c|c|c|}
\hline JRL & Vol. 12 & No. 1 & Hal : $01-14$ & $\begin{array}{c}\text { Jakarta, } \\
\text { Juni } 2019\end{array}$ & $\begin{array}{c}\text { p-ISSN : 2085.38616 } \\
\text { e-ISSN : 2580-0442 }\end{array}$ \\
\hline
\end{tabular}

\title{
POLA DAN SEBARAN SEDIMEN WILAYAH PERAIRAN BULUMINUNG, PENAJAM PASER UTARA
}

\author{
Sri Ardhyastuti, M.Si \\ Balai Teknologi Survei Kelautan, Badan Pengkajian dan \\ Penerapan Teknologi \\ Gd II BPPT, Lt. 12, Jl. MH. Thamrin No.8, Jakarta \\ E-mail: sri.ardhyastuti@bppt.go.id
}

\begin{abstract}
ABSTRAK
Kegiatan penelitian pola dan sebaran sedimen di perairan Buluminung Penajam Paser Utara dilaksanakan atas kerjasama Badan Pengkajian dan Penerapan Teknologi (BPPT) dan BAPPEDA Penajam Paser Utara, Kalimantan Timur. Penelitian ini dimulai sejak tahun 2013 hingga saat ini dengan analisa data yang dilakukan pada tahun 2016. Tujuan dari penelitian ini adalah untuk melakukan pemetaan jenis dan pola sebaran sedimen melalui identifikasi jenis batuan dan asal usul sedimen dengan analisa pengaruhnya terhadap lingkungan. Pola penyebaran sedimen dianalisa dari besar butir (granulometri) dengan sistem pengayakan dan penyaringan (sieving). Penyaringan menggunakan 5 buah ayakan dengan ukuran diameter berdasarkan skala Wentworth. Berdasarkan hasil analisa dari besar butir sedimen didominasi oleh kandungan pasir halus. Hal ini kemungkinan disebabkan oleh pengaruh rendahnya kecepatan arus, vegetasi mangrove, dan perubahan ekologi karena aktivitas manusia ataupun alam secara alamiah.
\end{abstract}

Kata kunci : granulometri, pesisir, lingkungan, pengendapan, Buluminung, Penajam Paser Utara 


\title{
PATTERNS AND DISTRIBUTION OF SEDIMENT AT BULUMINUNG WATER AREA, PENAJAM PASER UTARA
}

\begin{abstract}
Research on the pattern and distribution of sediments in Buluminung Penajam Paser Utara water area was carried out in collaboration between Agency for the Assessment and Application of Technology (BPPT) and BAPPEDA Penajam Paser Utara, East Kalimantan. This research was starting in 2013 and the data analysis was carried out in 2016. The purpose of this research was to mapping the distribution of sediment types and pattern through identification of rock types and the origin of sediments by analyzing their effects on the environment. The pattern of sediment distribution was analyzed from sediment grain size (granulometry) by sieving system. Process of sieving used 5 (five) different diameter of sieves based on Wentworth Scale. The data analysis resulted that the sediment are dominated by fine sands. These results are probably due to the influence of low current velocities, mangrove vegetation and ecological changes by human activities and/ or natural effects.
\end{abstract}

Key words : grain size sediment, coastal, environment, sedimentation, Buluminung, Penajam Paser Utara 


\section{PENDAHULUAN}

Indonesia adalah negara maritim yang sekaligus negara kepulauan terbesar di dunia dengan jumlah pulau mencapai 17.508 pulau dengan garis pantai sepanjang $81.000 \mathrm{~km}$ dan luas laut sekitar 3,1 juta $\mathrm{km}^{2}$. Sebagai Negara maritim, sudah seharusnya Indonesia memiliki pusat riset kelautan yang terpadu, dalam upaya mempercepat pembangunan maritim nasional. Salah satu kebijakan yang diambil pemerintah adalah membangun pusat teknologi kelautan yang disebut dengan National Science Techno Park Maritime (NSTP Maritim) yang berlokasi di Kabupaten Penajam Paser Utara (PPU). Program Maritime Technopark merupakan implementasi program yang digagas untuk menempatkan suatu pusat kajian, sebagai pilot projects sebelum diterapkan pada 100 lokasi lainnya diseluruh Indonesia. Salah satu pilot project tersebut adalah yang bertempat di Penajam Paser Utara (PPU) ini. Survei penempatan alat akustik tomografi pantai merupakan bagian yang tidak terpisahkan dalam rangka perencanaan pembangunan pilot project "maritime technopark" yang berada di Kabupaten PPU.

Kabupaten Penajam Paser Utara merupakan salah satu Kabupaten yang berada di kawasan pantai timur Kalimantan yang secara formal awalnya masuk dalam wilayah Kabupaten Paser. Tetapi, berdasarkan UU No. 7 tahun 2002 yang berisi tentang Pembentukan Kabupaten Penajam Paser Utara, maka Kabupaten ini terpisah dari kabupaten induknya (Kabupaten Paser). Secara geografis, Kabupaten Penajam Paser Utara berada pada $00^{\circ} 54^{\prime} 43,78^{\prime \prime}$ $01^{\circ} 30^{\prime} 00^{\prime \prime}$ LU dan 116 $27^{\prime} 40,54^{\prime \prime}$ $116^{\circ} 49^{\prime 21}, 08^{\prime \prime}$ BT. Kabupaten ini memiliki garis pantai sepanjang $\pm 15 \mathrm{~km}$ dan dengan garis pantai sepanjang itu tentunya Kabupaten Penajam Paser Utara memiliki potensi sumberdaya alam pesisir dan laut yang besar.

Badan Pengkajian dan Penerapan Teknologi (BPPT) melalui Kegiatan Pengkajian dan Penerapan Teknologi Survei Kelautan yang dilaksanakan oleh Pusat Teknologi Pengembangan Sumberdaya Wilayah (PTPSW) telah berkontribusi dalam membangun dan mengembangkan kemampuan teknologi survei laut. Teknologi tersebut meliputi berbagai aspek, seperti: survei eksplorasi, pemanfaatan dan konservasi sumberdaya laut (hayati dan non hayati), serta pembangunan dan pengembangan kemampuan dalam pengamatan dan pemantauan karakteristik lingkungan laut. Berbagai aspek teknologi survei laut tersebut diantaranya dapat diterapkan untuk tujuan mitigasi bencana kelautan. Oleh karena itu, kegiatan ini memerlukan dukungan infrastruktur berupa pusat pengkajian dan penerapan teknologi kelautan seperti dermaga, wahana survei dan peralatannya riset lain yang diikuti juga dengan sumberdaya manusia yang mempunyai kompetensi di bidang kelautan.

Dalam upaya untuk mendukung rencana pembangunan tersebut diatas maka diperlukan informasi yang mencakup semua aspek yang berhubungan baik secara teknis maupun non-teknis yang selanjutnya diterjemahkan dalam konsep kerekayasaan milik BPPT yang dibagi dalam beberapa kegiatan survei dan pengolahan dan informasi spasial yang nantinya menjadi dokumen teknis dalam mendukung penyediaan

Tujuan penelitian ini adalah mengidentifikasi jenis sedimen dan menentukan pola sebaran sedimen untuk mengetahui jenis batuan dan asal 
usul sedimen dan dampaknya terhadap lingkungan perairan/muara sungai Riko Buluminung Kabupaten Penajam Paser Utara.

\section{GEOLOGI REGIONAL DAERAH PENELITIAN}

Berdasarkan peta geologi, daerah Buluminung berada pada daerah aluvium
(Qa) yang merupakan endapan sungai dan danau. Di sekitar lokasi tersebut terdapat beberapa formasi, antara lain: Formasi Bebulu (Tmbl), Formasi Pulaubalang (Tmpb), Formasi Balikpapan (Tmbp), dan Formasi Kampungbaru (Tpkb), seperti yang terlihat pada gambar dibawah ini (Gambar 1).

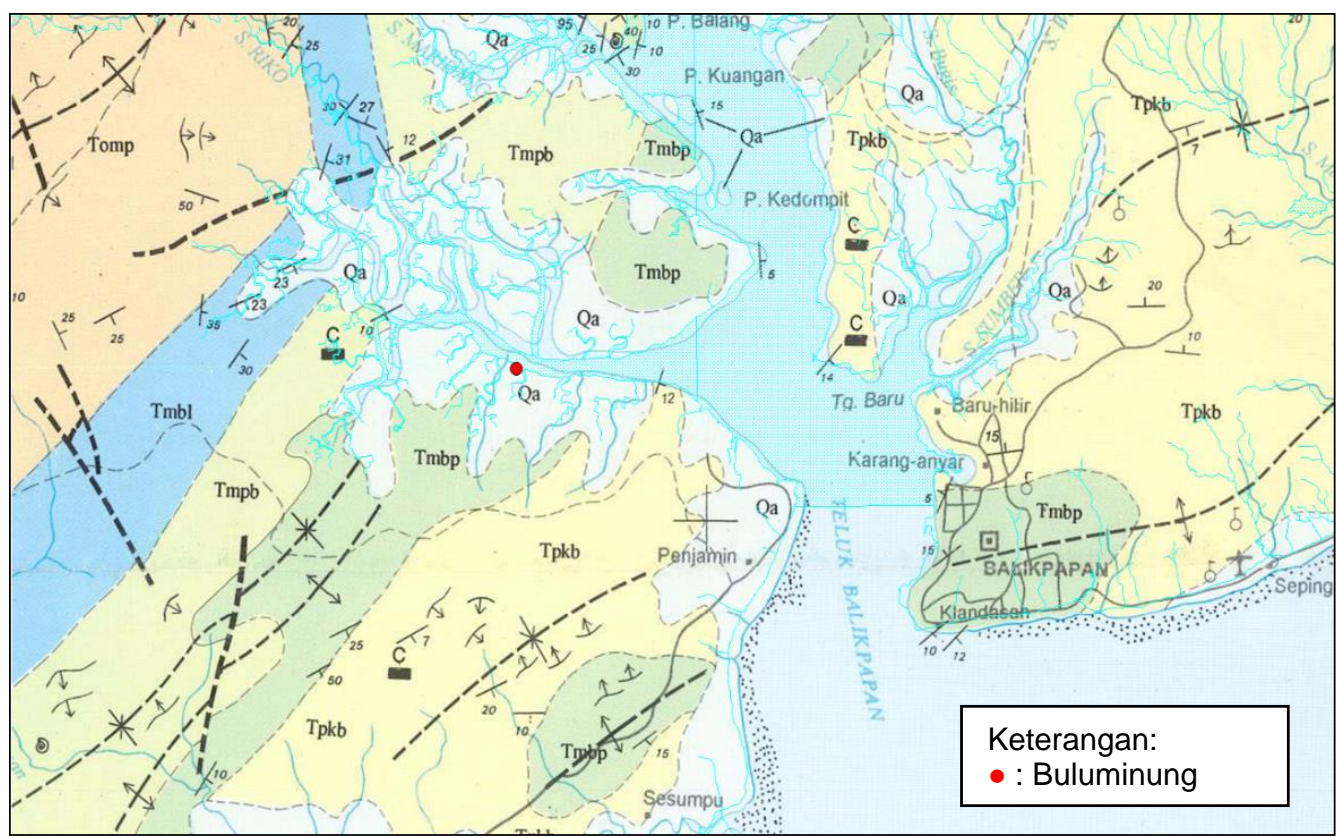

Gambar 1. Peta Geologi lembar Balikpapan (Hidayat dan Umar, 1994)

Hubungan antara formasi-formasi di atas ditunjukkan pada korelasi satuan sebagaimana dapat dilihat pada diagram di bawah ini (Gambar 2). 


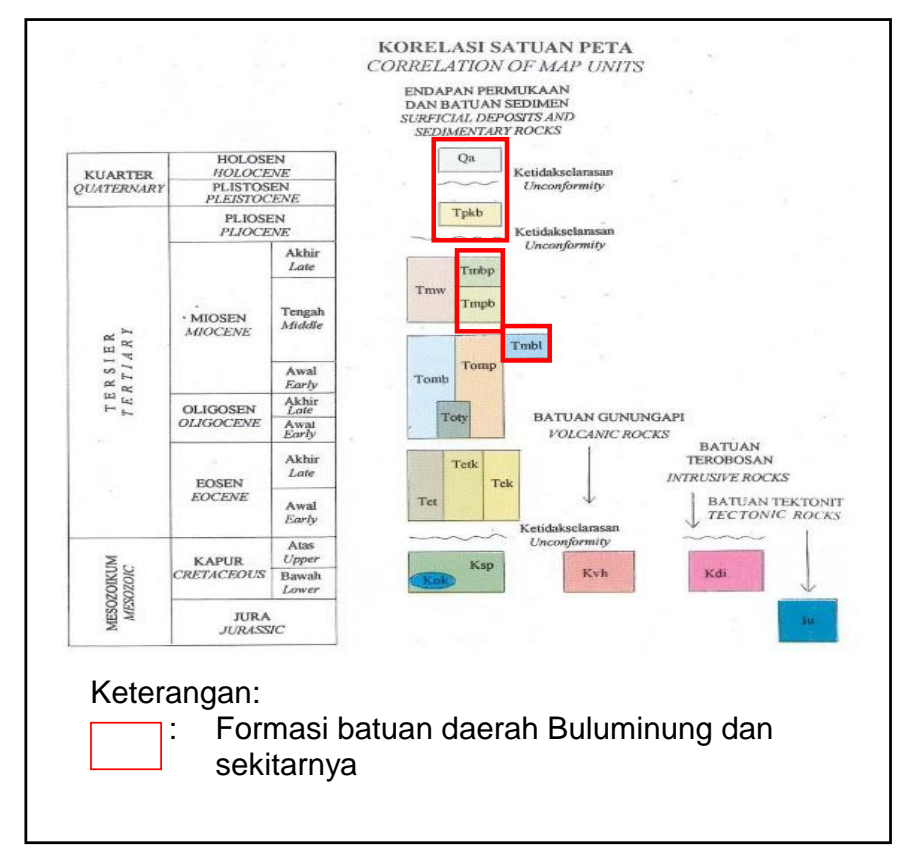

Gambar 2. Hubungan antar formasi batuan di daerah Buluminung.

Urutan formasi dari tua ke muda di daerah Buluminung dan sekitarnya adalah Formasi Bebulu (Tmbl), Formasi Pulaubalang (Tmpb), Formasi Balikpapan (Tmbp), dan Formasi Kampungbaru (Tpkb), dan Aluvium (Qa). Formasi tertua adalah Formasi Bebulu (Tmbl) yang berumur Miosen Tengah Bawah. Formasi ini tersusun atas batugamping terumbu dengan sisipan batugamping pasiran dan serpih. Hal ini menunjukkan bahwa formasi ini diendapkan pada lingkungan laut dangkal (marine shelf).

Di atas Formasi Bebulu (Tmbl), Formasi Pulaubalang diendapkan secara selaras (Tmpb) yang berumur Miosen Tengah. Formasi ini tersusun atas perselingan antara graywacke (batupasir yang kaya fragmen batuan metamorf, mika dan matrik batuan lempung mikaan) dan batupasir kuarsa dengan sisipan batugamping, batu lempung, batubara, dan tuf dasit. Komposisi batuan pada formasi ini menunjukkan bahwa formasi ini diendapkan pada lingkungan delta front hingga prodelta.

Selanjutnya masih diendapkan secara selaras di atas Formasi Pulaubalang (Tmpb) adalah Formasi Balikpapan (Tmbp). Formasi Balikpapan (Tmbp) tersusun atas perselingan batupasir dan lempung dengan sisipan lanau, serpih, batugamping dan batubara. Komposisi tersebut menunjukkan bahwa formasi ini diendapkan pada lingkungan delta plain pada umur Miosen Tengah Atas hingga Miosen Akhir Bawah.

$\mathrm{Di}$ atas Formasi Balikpapan diendapkan Formasi Kampungbaru (Tpkb) yang dibatasi oleh ketidakselarasan (unconformity) karena adanya gap waktu pengendapan. Formasi Kampungbaru (Tpkp) tersusun atas batupasir kuarsa dengan sisipan lempung, serpih; batugamping dan lignit. Formasi ini diendapkan pada lingkungan delta hingga laut dangkal dan berumur Pliosen. 
Formasi termuda berumur Holosen adalah endapan Aluvium (Qa) yang diendapkan tidak selaras di atas Formasi Kampungbaru (Tpkb) karena adanya gap waktu pengendapan. Maka dapat ditarik kesimpulan bahwa di daerah studi mengalami prograding (garis pantai menjorok maju) dan dua kali ketidakselarasan. Gambar 3 dibawah ini menunjukan uraian dari berbagai Formasi batuan.

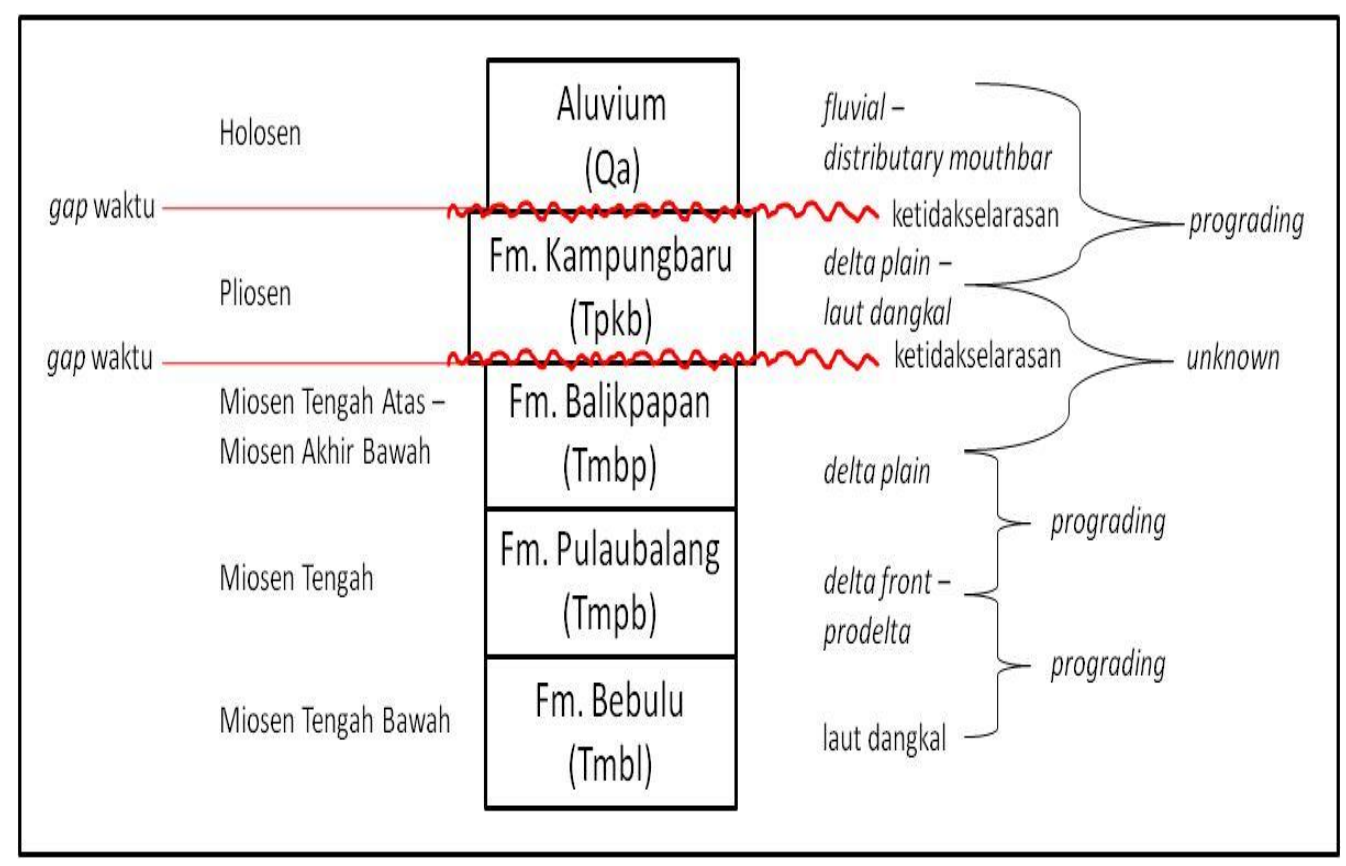

Gambar 3. Lithostratigrafi di Buluminung dan sekitarnya 


\section{METODE PENELITIAN}

Kegiatan survei ini merupakan kerjasama Bappeda Penajam Paser Utara dengan Balai Teknologi Survei Kelautan BPP Teknologi. Pengambilan sampel sedimen dilakukan pada tahun 2013 dan tahun 2016. Sampel sedimen diambil pada 9 (sembilan) titik pengambilan sampel pada tahun 2013 dan 11 titik pengambilan sampel pada tahun 2016 (Gambar 4). Pengambilan sampel dilakukan pada batas geografis 9948'54.49" - 99'51'49.28" BT dan 3०1'7.94" - 3013'37.83" LU dengan menggunakan Grap Sampler dan Gravity Core, dimana kemudian sampel dimasukan ke dalam kantong plastik dan di beri label nomor stasiun.

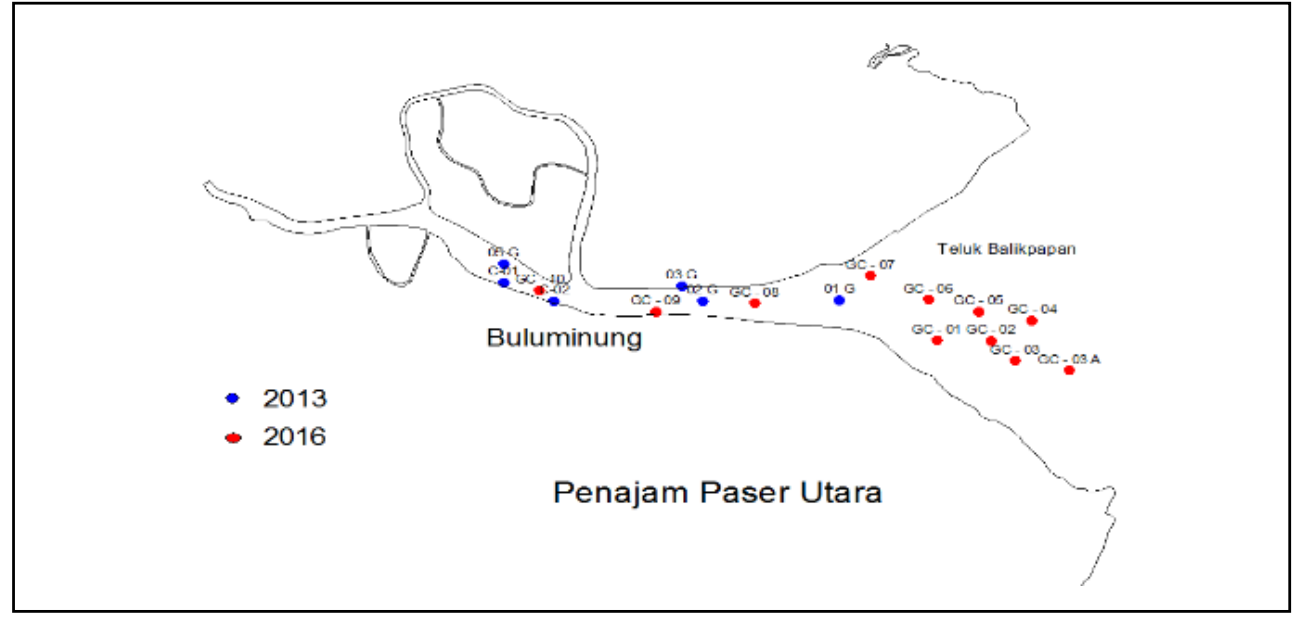

Gambar 4. Peta lokasi pengambilan sampel sedimen dimana warna biru menunjukan stasiun pengambilan sampel pada tahun 2013 dan warna merah menunjukkan stasiun pengambilan sampel pada tahun 2016.

Analisa besar butir adalah suatu proses pemisahan butiran sedimen / batuan dari butiran yang sangat halus sampai sangat kasar. Analisa ini bertujuan untuk mengetahui komposisi dan tekstur butiran sedimen, sehingga bisa ditentukan jenis atau nama sedimen tersebut. Selain itu analisis juga ditujukan untuk mengetahui penyebaran padatan tersuspensi dan sedimen dasar serta untuk mengetahui kecepatan pengendapan sedimen dasar perairan. Metoda analisa granulometri atau besar butir dilakukan dengan sistem pengayakan / penyaringan (sieving). Saringan (sieve) yang digunakan ada 5 (lima) buah dengan besar diameter saringan yang berbeda yang merupakan batas jenis besar butir menurut skala Wentworth (Wentworth, 1922). Saringan yang memiliki lebar bukaan lebih besar dari 0,5 mm akan menghasilkan ayakan yang merupakan pasir kasar (coarse sand) sampai kerakal-kerikil. Sedangkan saringan yang memiliki bukaan lebih besar dari 0,25 $\mathrm{mm}$ adalah pasir sedang (medium sand) dan yang memiliki bukaan lebih besar dari 0,125 mm, akan menghasilkan pasir halus (fine sand). Saringan yang memiliki bukaan lebih besar dari 0,063 $\mathrm{mm}$ menghasilkan pasir sangat halus (very fine sand), sedangkan yang bukaannya lebih besar dari 0,002 $\mathrm{mm}$ akan menghasilkan adalah lumpur ( $m u d$ ), dan yang lolos dari ukuran lebih kecil dari 0,002 $\mathrm{mm}$ adalah material 
terlarut. Setelah diayak, sampel sedimen yang tertinggal pada setiap ukuran saringan dikeringkan dalam oven untuk ditimbang masing-masing beratnya sehingga diperoleh distribusi berat sedimen berdasarkan rentang ukuran kerapatan jaring saringan (Sheppard, 1954;, Folk 1974, Poerbandono \& Djunasjah, 2005). Perhitungan untuk jumlah besar butir ini dilakukan dengan pengurangan jumlah sampel sedimen awal dengan jumlah sampel sedimen yang tertahan dalam saringan. Data yang diperoleh dibuat dalam bentuk grafik yang menunjukan prosentase besar butir sedimen sehingga menunjukan besarnya prosentase kandungan lumpur pada sedimen dimana sangat mempengaruhi terhadap lingkungan perairan.

\section{HASIL DAN PEMBAHASAN}

\subsection{Besar Butir Sedimen}

Hasil analisa besar butir sedimen di perairan Buluminung Kabupaten Penajam Paser Utara didapatkan 3 (tiga) satuan sedimen yaitu sedimen pasir (sand), pasir lumpuran (muddy sand), dan lumpur pasiran (sandy mud) (Tabel
1 dan 2). Secara umum jenis sedimen yang dominan di daerah penelitian adalah sedimen pasir lumpuran (mudy sand). Satuan ini memiliki prosentase pasir $56,16 \%$ sampai dengan $78,25 \%$. Satuan pasir yang ditemukan berwarna abu-abu, kecoklatan, berbutir halus sampai sedang, lunak, mengandung fragmen pecahan cangkang kerang, fragmen batubara, dan fragmen tumbuhan. Adanya fragmen pecahan cangkang kerang mencirikan bahwa endapan ini berasal dari endapan marine sedangkan adanya fragmen batubara dan tumbuhan, dimana mencirikan endapan tersebut hasil rombakan daratan. Satuan lumpur pasiran memiliki kandungan pasir sekitar 30\%-40\%, berwarna abu abu kecoklatan dan bersifat lunak.

Dilihat dari karakteristik batuan diatas, diperkirakan sedimen tersebut merupakan rombakan batuan dari Formasi Balikpapan dan Formasi Kampung baru, seperti yang dijelaskan diatas bahwa Formasi Balikpapan dan Formasi Kampung baru merupakan formasi yang tersusun atas perselingan batupasir dan lempung dengan sisipan lanau, serpih, batu gamping dan batubara. 
Tabel 1. Hasil Analisa Sedimen Perairan Pantai Penajam Paser Utara tahun 2013

\begin{tabular}{|c|c|c|c|c|c|c|c|c|c|c|}
\hline \multirow[b]{2}{*}{ NO } & \multirow[b]{2}{*}{$\begin{array}{l}\text { NAMA } \\
\text { SAMPEL }\end{array}$} & \multirow[b]{2}{*}{ LITOLOGI } & \multicolumn{8}{|c|}{ KANDUNGAN (\%) } \\
\hline & & & PASIR & LUMPUR & KERIKIL & $\begin{array}{l}\text { PASIR } \\
\text { SANGAT } \\
\text { KASAR }\end{array}$ & $\begin{array}{l}\text { PASIR } \\
\text { KASAR }\end{array}$ & $\begin{array}{l}\text { PASIR } \\
\text { SEDANG }\end{array}$ & $\begin{array}{l}\text { PASIR } \\
\text { HALUS }\end{array}$ & $\begin{array}{c}\text { PASIR } \\
\text { SANGAT } \\
\text { HALUS }\end{array}$ \\
\hline 1 & $01 \mathrm{G}$ & Pasir Lumpuran & 74.41 & 25.59 & 2.60 & 5.21 & 7.81 & 10.42 & 42.36 & 6.02 \\
\hline 2 & $02 \mathrm{G}$ & Pasir & 99.90 & 0.10 & 1.36 & 1.07 & 2.92 & 7.07 & 85.11 & 2.38 \\
\hline 3 & $03 \mathrm{G}$ & Pasir & 99.97 & 0.03 & 5.37 & 2.67 & 4.72 & 39.76 & 46.92 & 0.54 \\
\hline 4 & $04 \mathrm{G}$ & Pasir lumpuran & 70.13 & 29.87 & 0.47 & 0.94 & 1.41 & 1.88 & 59.95 & 5.46 \\
\hline 5 & $05 \mathrm{G}$ & Pasir & 99.73 & 0.27 & 0.97 & 1.26 & 5.21 & 23.87 & 66.76 & 1.66 \\
\hline 6 & Core 01 & Pasir lumpur & 49.43 & 50.57 & & & & 0.26 & 33.27 & 15.90 \\
\hline 7 & Core 02 & Pasir lumpuran & 62.47 & 37.53 & & & & 0.98 & 29.96 & 31.53 \\
\hline 8 & Core $03 \mathrm{t}$ & Pasir lumpur & 56.14 & 43.86 & & & & 0.69 & 35.76 & 19.68 \\
\hline 9 & Core $03 \mathrm{~b}$ & Pasir lumpuran & 65.96 & 34.04 & & & & 1.11 & 50.22 & 14.63 \\
\hline
\end{tabular}


Tabel 2. Hasil Analisa Sedimen Perairan Pantai Penajam Paser Utara tahun 2016

\begin{tabular}{|c|c|c|c|c|c|c|c|c|c|c|}
\hline \multirow[b]{2}{*}{ NO } & \multirow[b]{2}{*}{$\begin{array}{l}\text { NAMA } \\
\text { SAMPEL }\end{array}$} & \multirow[b]{2}{*}{ LITOLOGI } & \multicolumn{8}{|c|}{ KANDUNGAN (\%) } \\
\hline & & & PASIR & LUMPUR & KERIKIL & $\begin{array}{c}\text { PASIR } \\
\text { SANGAT } \\
\text { KASAR }\end{array}$ & $\begin{array}{l}\text { PASIR } \\
\text { KASAR }\end{array}$ & $\begin{array}{l}\text { PASIR } \\
\text { SEDANG }\end{array}$ & $\begin{array}{l}\text { PASIR } \\
\text { HALUS }\end{array}$ & $\begin{array}{c}\text { PASIR } \\
\text { SANGAT } \\
\text { HALUS }\end{array}$ \\
\hline 1 & GC - 01 & Pasir lumpuran & 70.18 & 29.82 & 2.58 & 0.71 & 0.70 & 5.75 & 57.16 & 3.28 \\
\hline 2 & GC - 02 & Pasir lumpuran & 70.71 & 29.29 & 3.26 & 2.80 & 2.08 & 1.64 & 52.48 & 8.65 \\
\hline 3 & GC - 03 & Pasir lumpuran & 78.25 & 21.75 & 1.09 & 0.94 & 1.56 & 6.35 & 53.74 & 14.83 \\
\hline 4 & $G C-03 A$ & Pasir lumpuran & 70.00 & 30.00 & 2.40 & 1.32 & 1.05 & 1.69 & 54.89 & 8.86 \\
\hline 5 & GC - 04 & Pasir lumpuran & 54.95 & 45.05 & 1.45 & 1.53 & 1.53 & 1.93 & 27.88 & 20.91 \\
\hline 6 & GC - 05 & Pasir lumpuran & 65.71 & 34.29 & 2.63 & 1.38 & 1.17 & 1.70 & 47.25 & 12.22 \\
\hline 7 & GC - 06 & Pasir lumpuran & 63.57 & 36.43 & 4.61 & 1.80 & 1.67 & 3.61 & 45.83 & 6.17 \\
\hline 8 & GC - 07 & Lumpur pasiran & 48.11 & 51.89 & 0.91 & 0.58 & 0.75 & 1.48 & 19.46 & 25.33 \\
\hline 9 & GC - 08 & Pasir & 90.36 & 9.64 & 10.05 & 0.59 & 0.51 & 1.21 & 75.57 & 2.82 \\
\hline 10 & GC - 09 & Lumpur pasiran & 31.73 & 68.27 & 0.70 & 0.43 & 0.87 & 3.24 & 14.50 & 12.32 \\
\hline 11 & GC - 10 & Lumpur pasiran & 38.86 & 61.14 & 0.59 & 0.12 & 0.29 & 1.65 & 26.67 & 9.73 \\
\hline
\end{tabular}




\subsection{Penyebaran Sedimen.}

Menurut Boggs (1987), ada 3 (tiga) faktor yang mempengaruhi ukuran butir batuan sedimen, yaitu variasi ukuran butir sedimen asal, proses transportasi, dan energi pengendapan. Data-data hasil analisis ukuran butir sedimen tersebut digunakan untuk mengetahui 3 faktor tersebut secara jelas.

Pengaruh daratan terhadap perairan sekitarnya sangat jelas terutama pada saat terjadi hujan didaerah hulu sungai dimana air sungai yang coklat keruh mengalir dari hulu sungai menuju ke laut. Pada saat itu kekeruhan air akibat transportasi material suspensi dari daratan cukup tinggi. Sedimen pasir yang dibawa aliran sungai dan diendapkan di mulut sungai dan sekitarnya. Lanau dan lumpur diendapkan pada permukaan dasar perairan yang jauh dari mulut sungai (Selley, 1976 dalam Helfinalis, 2000).
Sedimen yang halus diendapkan di daerah estuarin (Postma, 1961, 1967 dalam Helfinalis, 2000). Di perairan delta, pasir diendapkan disekitar mulut sungai sedangkan lanau halus dan lempung diendapkan jauh ke tengah laut (Davis, 1978 dalam Helfinalis, 2000).

Salah satu fungsi dari sungai ini adalah mengalirkan air tawar dan material lain dari daratan ke perairan sekitarnya. Material organik dan suspensi dari daratan langsung tercurah ke perairan ini setiap saat dan volume akan bertambah besar di musim hujan (musim timur). Sungai Penajam Paser Utara sebagai penyumbang material sedimen, bahan organik dan suspensi di dasar perairan.

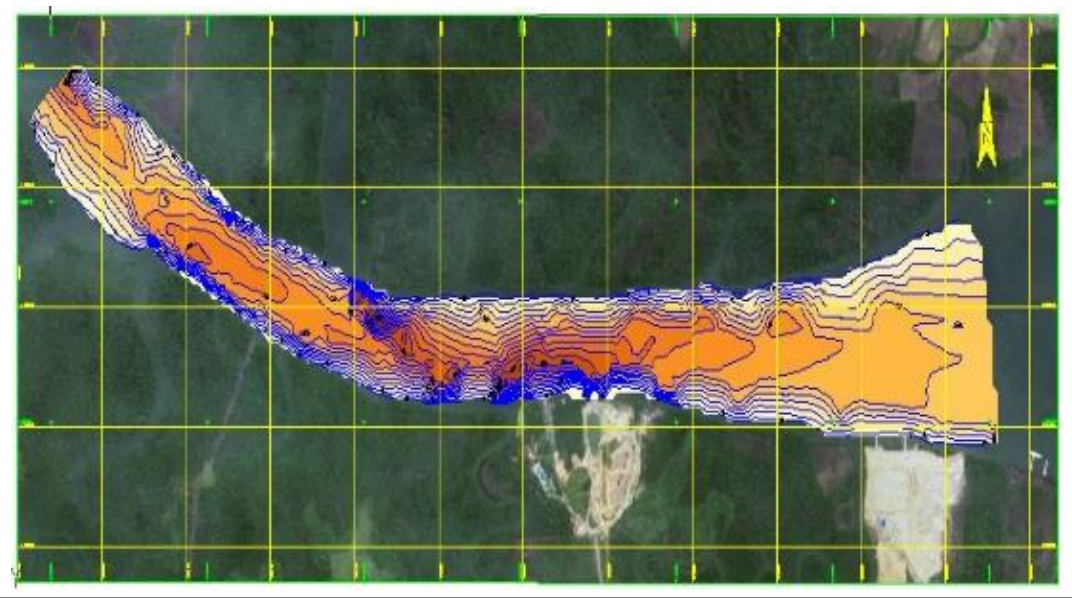

Gambar 5. Peta batimetri di perairan sekitar Buluminung Kabupaten Penajam Paser Utara 


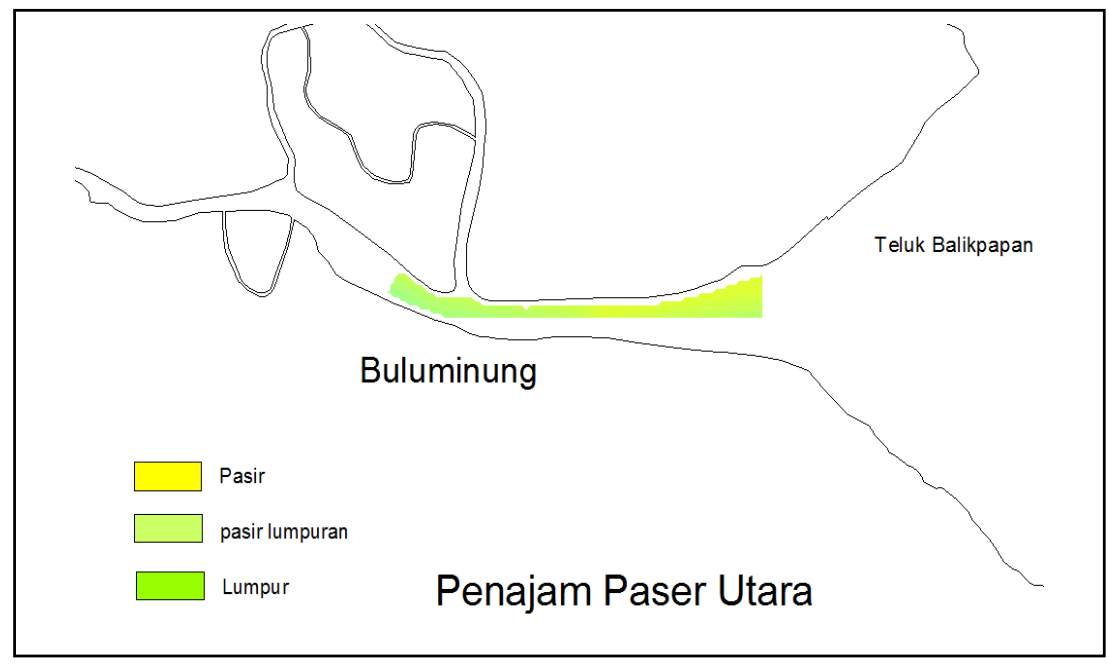

Gambar 6. Pola Sebaran Sedimen di perairan sekitar Kabupaten Penajam Paser Utara

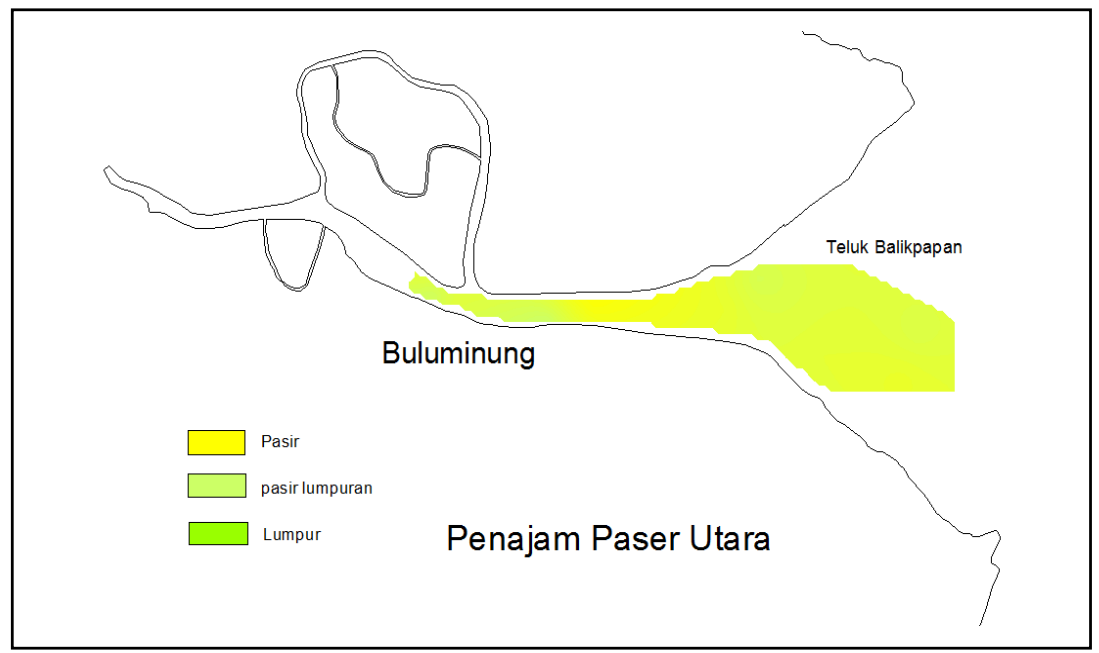

Gambar 7. Pola Sebaran Sedimen di perairan sekitar Kabupaten Penajam Paser Utara

Dari peta topometri dan Buluminung bisa mencapai 30 meter kemiringan dasar laut (Gambar 5), sedangan sebelah barat dan timur menunjukkan bahwa kondisi topografi wilayah perairan Buluminung berkisar 5perairan Sungai Riko Buluminung tampak adanya Cekungan ditengah tengah dan tepatnya di daerah Buluminung. Kedalaman perairan 15 meter.

Berdasarkan peta sebaran sedimen (Gambar 6 dan Gambar 7) dapat dilihat bahwa pola sedimen 
permukaan banyak dipengaruhi oleh sungai yang memasok material lumpur ke lokasi survei dan batuan yang mengendap dilapisan atas dasar laut. Batuan dari batuan Kuarter dari darat yang mengalami penggerusan oleh gelombang dan arus laut. Hal ini sudah berlangsung cukup lama sehingga membentuk rupa batuan sedimen terdiri dari butir pasir halus berbentuk bundar dan oval. Sedimen lumpur dijumpai di seluruh daerah yang diteliti. Untuk proses sedimentasi di daerah muara sungai Penajam Paser Utara, dipengaruhi oleh hasil rombakan dari daerah dataran tinggi (hinterland). Lebih lanjut Dyer (1986) menjelaskan bahwa sedimen dengan ukuran yang lebih halus lebih mudah berpindah dan cenderung lebih cepat daripada ukuran kasar. Fraksi halus terangkut dalam bentuk suspensi sedangkan fraksi kasar terangkut pada dekat dasar laut. Selanjutnya partikel yang lebih besar akan tenggelam lebih cepat daripada yang berukuran kecil.

Seperti yang sudah dijelaskan pada bagian komposisi batuan, bahwa batuan ini mengandung fragmen pecahan cangkang kerang, fragmen batubara, dan fragmen tumbuhan dan diperkirakan bahwa sedimen ini merupakan hasil rombakan batuan Formasi Balikpapan dan Formasi Kampung baru. Penyebaran satuan sedimen pasir berada di perairan sebelah timur Buluminung sampai Muara Sungai Riko sampai batas Teluk Balikpapan sedangkan penyebaran satuan sedimen pasir lumpuran meliputi $70 \%$ daerah penelitian, meliputi bagian barat, timur dan di sekitar daerah perairan Buluminung.

\section{KESIMPULAN}

Dari hasil penelitian ini dapat disimpulkan bahwa:

- Hasil analisa besar butir sedimen di perairan Sungai Riko Buluminung
Kabupaten Penajam Paser Utara, didominasi oleh kandungan pasir lumpuran dengan sebaran sekitar $70 \%$, meliputi bagian barat dan timur wilayah penelitian.

- Dari topografi daerahnya menunjukan bahwa sepanjang muara Sungai Riko terdapat adanya cekungan ditengah tengah sungai tepatnya di daerah Buluminung dan cekungannya atau lembah yang berada di bawah permukaan air pada umumnya terisi oleh material lumpur.

- Sedimen yang terdapat di Perairan Sungai Riko merupakan rombakan dari batuan Formasi Balikpapan dan Formasi Kampung baru, terdiri dari batuan pasir dengan perselingan dengan batu lempung dan sisipan batubara. Hal tersebut terlihat dari fragmen batubara pada sedimen.

\section{DAFTAR PUSTAKA}

Boggs Jr., S. 1987, Principles of sedimentology and stratigraphy, Prentice Hall, Inc., New Jersey.

Dyer, K.R.1986. Coastal and Estuary Sediment Dynamic. John Willey \& Sons. New York.

Helfinalis., 2000. Endapan Sedimen Di Dasar Perairan Kalimantan Timur. Proceeding of Indonesian Association of Geologist. The 29 $9^{\text {th }}$ Annual Convention.

Poerbandono \& E. Djunasjah. 2005. Survei Hidrografi. Refika Aditama. Bandung. Reineck, H.E., \& Singh, I.B., 1986. Depositional Sedimentary Environments, 2nd ed. Springer, Berlin.

Sheppard, E.P. 1954. Nomenclature based on sand silt clay ratios. Journal of Sediment and Petrology, 24(4): 151 - 158. 
S. Hidayat dan L. Umar (1994), Peta Geologi Lembar Geologi, Kalimantan. Pusat Penelitian dan Pengembangan Geologi

Wentworth, C.K. 1922. A scale of grade and class term for clastic sediment. Geology, 30: 337 392. 